\title{
How to participate in ACRL
}

\section{Information for new members and potential members.}

To join

Write or call the Association of College and Research Libraries for application forms and information: ACRL Office, $50 \mathrm{E}$. Huron, Chicago, IL 60611-2795; (800) 545-2433; in Illinois, (800) 5452444; in Canada, (800) $545-2455$; or (312) $944-$ 6780.

To learn about ACRL's current programs, officers, and units

Check the ALA Handbook of Organization and read College \& Research Libraries News regularly (as a member of ACRL, you will receive both publications).

To attend conference programs, ACRL Board meetings, or committee meetings

For information on time, places, and general program content, consult $C \& R L$ News, American Libraries, and the official conference programs and schedules. For additional information, contact the ACRL office.

\section{To attend preconferences}

For information about time, place, and preconference theme, consult $C \& R L$ News and American Libraries. For additional information and registration materials, write to the ACRL office.

\section{To take a continuing education course}

To receive a course brochure, write to the ACRL office. To register, use information published in $C \downarrow R L$ News or in the course brochure.

To sponsor a local presentation of an ACRL continuing education course

Write the ACRL office and specify the course(s) and date(s). ACRL continuing education courses are available for local presentation by chapters, library schools, libraries, universities, or other professional groups.
To establish a local chapter of ACRL

Check the procedures listed in "Guidelines for ACRL Chapters" (available from the ACRL office). Send a petition with the signatures of at least 25 ACRL members to the ACRL office for approval by the Board of Directors.

To request a speaker in the Chapter Speaker program

Write Alia Al-Taqi at the ACRL office and specify your date and topic. Eight chapters qualify each year for a free visit from ACRL officers or the ACRL Executive Director.

To serve on ACRL's committee or to participate in ACRL's sections and discussion groups

Familiarize yourself with the work of the unitcheck the ALA Handbook of Organization for the unit's statement of responsibility, read about the work of the unit as reported in C $b R L$ News and American Libraries, attend the meetings of the unit during ALA conferences. Submit a completed ACRL committee volunteer form (published in the October issue of C $d R L$ News and available at ALA conferences). Communicate your interest to the ACRL Appointments and Nominations Committee, to any of the ACRL officers, to the chair of an ACRL unit whose work interests you, or to the ACRL office.

\section{To be a candidate for an ACRL office}

Write to the ACRL Appointments and Nominations Committee or to an ACRL section nominating committee. Submit a petition to have your name added to the list of candidates.

To nominate someone for an award or to apply for a grant or fellowship

Write or call Mary Ellen Davis at the ACRL office for information or nomination forms for the 
Academic/Research Librarian of the Year Award, Oberly Award, Doctoral Dissertation Fellowship, Hugh Atkinson Memorial Award, Samuel Lazerow Fellowship, the Miriam Dudley BI Librarian of the Year Award, the RBMS Exhibition Catalogue Award, or the Martinus Nijhoff International West European Specialist Study Grant.

To provide suggestions for new projects, services, courses, and policies

Write to the ACRL office, to any of the ACRL officers, or to the chair of a unit whose work relates to the matter. Respond to requests published in $C \& R L N e w s$ for suggestions from the membership. Attend open hearings scheduled at ALA conferences. Be in touch with the ACRL Planning Committee (Carolyn Dusenbury, chair).

To receive information, assistance, or advice on professional problems

Contact the ACRL office, any of the ACRL officers, or the chair of an ACRL unit whose work relates to the matter.

To find information on professional library positions open

Check the classified advertising listings in College \& Research Libraries News or American Libraries. Subscribe to the monthly Fast Job Listing Service, available from the ACRL office. Call the ACRL telephone JOBLINE, (312) 944-6795 (listings are changed every Thursday afternoon).

To obtain ACRL publications or policy statements

For information about the availability of materials, check C\&RL News, ACRL's publications brochure, or the ALA Publications Checklist. You may obtain a publications brochure from the ACRL office or at ALA conferences. To order standards and guidelines, write to the ACRL office. To order other publications, contact the ALA Order Department.

\section{To submit an article for publication}

Contact the editor of the publication. For $\mathrm{Col}$ lege \& Research Libraries, send manuscripts to Charles R. Martell, California State University Library, 2000 Jed Smith Drive, Sacramento, CA 95819. Instructions for authors are printed in each issue of the journal. For C $b R L$ News, send articles to George Eberhart at the ACRL office (see the guidelines published in January). For Rare Books \& Manuscripts Librarianship, send articles to Alice Schreyer, Special Collections, University of Delaware Library, Newark, DE 19717.

To submit a proposal for a monographic publication

Discuss your proposal with Mary Ellen Davis, ACRL publications officer, at ACRL headquarters, and submit a "Preliminary Publication Information Form." Consult this issue of C $U R L$ News, p. 159, for more detailed instructions. For the ACRL Publications in Librarianship series, send proposals or manuscripts directly to Jonathan A. Lindsey, Coordinator of Affairs, Baylor University, Waco, TX 76798.

To submit news items for publication in College Research Libraries News

Send materials to George Eberhart at the ACRL Office, 50 E. Huron St., Chicago, IL 60611-2795. Consult the guidelines for submission of news items in the January issue. The deadline for receipt of news items is approximately the 26th of each month.

\section{To subscribe to ACRL periodicals}

For a subscription to Choice, write to the Subscriptions Department, Choice, 100 Riverview Center, Middletown, CT 06457. For a subscription to $C \& R L$ or $C \& R L$ News, write to the Subscriptions Department, American Library Association, 50 E. Huron St., Chicago, IL 60611-2795.

\section{To order works from the ACRL Publications in Li- brarianship series}

For a listing of the works in this series, write to the ACRL office. For a list of in-print titles, check the "List of ACRL materials available," featured in this issue. To place a standing order or to order individual titles, write to the ALA Order Department, 50 E. Huron St., Chicago, IL 60611-2795. To order copies of out-of-print titles, contact University Microfilms International, 300 N. Zeeb Rd., Ann Arbor, MI 48106.

\section{To advertise in ACRL publications}

To place product ads in $C \mho R L, C \& R L N e w s$, or Choice, contact Art Beck, Advertising Sales Manager, Choice, 100 Riverview Center, Middletown, CT 06457. To place classified ads in C\&RL News, or job listings in the Fast Job Listing Service or the telephone JOBLINE, contact Cheryl RobinsonSmith at the ACRL Office, 50 E. Huron St., Chicago, IL 60611-2795; (312) 944-6780, ext. 286.

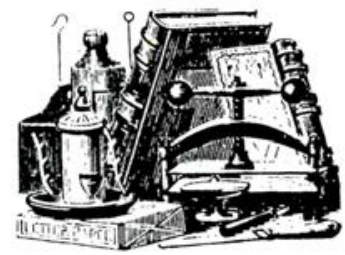

